\title{
A GOOD DEATH or a SHAMEFUL END?
}

(Death in Mid-Nineteenth-Century Lithuanian Culture)

\section{Vladas SIRUTAVIČIUS \\ Lithuanian Institute of History}

This study was conceived initially as an attempt to research the dynamics of suicide in the nineteenth-century Lithuania and to establish its causes. The choice of the problem was prompted by social processes taking place in post-Communist Lithuanian society, in particular by a sudden rise in the numbers of suicides. ${ }^{1}$ In the opinion of specialists the spread of suicides is becoming a serious social problem, requiring an urgent analysis of its roots and possible ways of its solution. ${ }^{2}$ In the analysis of the phenomenon of suicide so far, however, researchers have paid less attention to the ways in which society viewed various forms of death, its condemnation or justification.

The present paper deals with several major topics. It presents a reconstruction of a variety of contradictory attitudes, prejudices and feelings towards suicides among the nineteenth-century Lithuanian general public - from the sinner and offender to the victim and the sick, from scorn and hatred to sympathy. An attempt is also made to determine the causes behind the formation of a particular viewpoint. The paper does not examine the professional interpretation of suicide (by doctors, police officers), nor does it unravel the influence of rational scientific ideas in contemporary society (e.g., the particular social or psychiatric motivation behind suicidal behaviour); instead, emphasis is placed on the treatment of related issues at the non-specialist level. The second part of the paper examines the experience of death typical of the nineteenth-century culture. The present research was definitely influenced by the traditions of Western European scholarship, in particular by the works of Philippe Ariès and Norbert Elias.

In the most general terms, two attitudes towards suicide could be distinguished in nineteenth-century Lithuanian culture: the official

'According to the data of the Lithuanian Department of Statistics the suicide rate were 27.1 per 100,000 in the country in 1989, 26.0 - in 1990, as many as 42.1 - in 1993 and cven 45.8 - in 1994; sce Lietuvos statistikos departamentas. Demografijos metraštis, Vilnius, 1994, 68-69.

${ }^{2}$ An interpretation of the dynamics of suicide is presented adequately in: V. Domanskicnc and D. Gailicnc "Savižudybių paplitimas Lictuvoje" (The spread of suicides in Lithuania). Vilniaus Universiteto Mokslo darbai. Psichologija, nr. 1 (12), 1992. 
(religious, or bureaucratic) and the general (ordinary, everyday). This paper actually deals with the relationship of these two attitudes. Doubtless, the supposition of the existence of several tendencies in the interpretation of this social phenomenon might raise serious doubts. For example, the cultural historian Vytautas Kavolis criticized psychohistorians for their fervent wish to distinguish several dominating or major tendencies in public imagination and sensibility and maintained that historians often fell into a trap of their own invented schemes, as they moved away from contradictory reality. ${ }^{3}$ Taking that into account, the importance of those interpretation schemes for research should not be exaggerated.

Some comments on the title of this article might also be relevant. According to a view, widespread in nineteenth-century Lithuanian society death 'comes' unexpectedly. Therefore, no one knows the hour of his death. However, it is both possible and indeed a duty to 'prepare' for one's death. In that culture two types of death could be distinguished: honourable or fit and dishonourable or improper. The latter type is a sudden, unexpected death; as a rule, suicides were attributed to that category, too. People should avoid such death, because it prevents the soul's getting into heaven. Its opposite is a good or honourable death, which occurs after proper preparation. That type of death is crucial, since it alone guarantees eternal life.

" ... for reasons unknown to me, I resolved to commit this offence ..."

That statement was made by a sixty-year-old herdsman, Jonas Čyvilis, from the village of Paberžé, in the Pavandene district of the county of Telšiai, after he had been accused of attempted suicide. His evidence was recorded by Ignotas Dobkevičius under the supervision of a police officer. That event took place in October $1864 .{ }^{4}$ The case itself and its investigation were typical - similar lawsuits were always conducted in this manner in the mid-nineteenth century.

At first the criminal was examined by the doctor and a certificate of forensic examination was issued. However, not all case files contain such certificates. At the turn of the century and even later such certificates were not required, because doctors were few. Instead, psychiatric 'expertise' was carried out by a police official on the basis of the evidence given by witnesses, mostly members of the family and

${ }^{3}$ V. Kavolis. Kultūrinè psichologija, Vilnius: Baltos lankos, 1995, 7-8.

${ }^{4} \mathrm{~A}$ health certificate of Jonas Čyvilis, issued by the physician collegiate assessor Andžejevičius on 1 October 1864; an undated record of Čyvilis' interrogation, carried out by a police officer of Pavandenc; the casc was forwarded to the county court of Telšiai and was investigated by the inspector of the first police district. Witnesses were called to give cvidence; interrogation records no. 1, and no. 3 (28 August 1865); the offender himself was interrogated once more; record no. 4 (10 October 1865); all the materials, related to the casc, were sent to the county court of Telšiai; sec LVIA, f. 669, ap. 419, 1. 3, 4-5, 9-10, $14,17-18$. 
neighbours. Afterwards the offender was interrogated by the police and the case was sent to the county court for investigation. The court appointed an official investigator to conduct a 'formal interrogation'. The main task of both the physician and the interrogator was to establish whether the person, who had committed a given crime, was 'in his right mind'. Examining the motives behind the crime was also of great importance. Particular attention was paid to the testimonies of witnesses, who as a rule testified under oath.

In the words of the witnesses, in general, the herdsman was good-natured and well-behaved, only he used to drink heavily. After a drinking-bout he was 'like a madman'. That was the only condemnation his fellow villagers could lay against him. That argument seemed insufficient for the interrogator and the court. They decided that the herdsman was not insane and that he had intended to commit suicide 'for no apparent reason'. Accordingly, he was found guilty. For that 'unlawful act' he had to repent - by praying, fasting and learning the catechism. Thus, he had to prepare himself for the most important thing - making his confession.

In that way the formal (official) conception of suicide became established around the middle of the nineteenth century and it remained unchanged until the end of the century. It is worth noting that by the beginning of 1840s the criminal code of the Russian Empire treated suicide as a criminal offence. According to the Svod Zakonov Ugolovnykh (Code of Criminal Laws) of 1842, if a person, having attempted to commit suicide, was 'in his right mind', and the reasons of suicide were not 'pains, sorrow, shame, fiery or melancholic illnesses', he must be punished 'as for the attempt upon somebody's life'. Such 'criminals' were to be buried without the usual Christian burial ceremony. According to the Military Ustav of the Empire, those, who 'destroyed themselves', had to be buried by the public executioner. 5 Religious norms and interpretations profoundly influenced the penal code, because divine will was one of the major premises of the legitimacy of any secular political power. No wonder that in the Russian Empire as well as in many countries of Western Europe suicide was treated as a crime.

The same penal code was introduced in the lands of historic Lithuania, after it had been incorporated into the Russian Empire. True, its practical application is not known in greater detail. By the estimates of mid-nineteenth-century authors, there were 533 cases of suicide in the province of Vilnius between 1834 and 1841. Thus, the annual average suicide rate would be 5.1 per 100,000 . However, these data are neither reliable nor exact. Firstly, contemporary commenta-

${ }^{5}$ Svod Zakonov Ugolovnykh. St. Pctcrsburg, 1842, 82.

${ }^{6} \mathrm{~K} . \mathrm{S}$. Vesclovskii. Opyt nravstvennoi statistiki Rossii (An analysis of moral statistics in Russia). Zhurnal Ministerstva Vnutrennikh Del, chast' 18, 1847, 198-199. 
tors did not pay any particular attention to the critical analysis of statistical data. Secondly, due to the poor professional competence of police officers a number of deaths remained unaccounted for, that is, their causes were not established. Among them there might have been suicides. It should be noted that such a situation existed even until the end of the century. Thirdly, people used to keep such deaths or attempted suicides secret, especially in the countryside, in an attempt to avoid contact with the police, and possible persecutions and fines. It is quite believable that some suicides were not recorded by the police and the total number must have been greater than the one indicated by statistics from the first half of the nineteenth century.

In the Criminal Code, re-issued in 1845, suicide was no longer treated as a criminal offence, and punishment became milder. In Western Europe suicide began to disappear from penal codes in the second half of the eighteenth century. In official documents and in the correspondence between law courts and police officials suicide was still referred to as a crime. If it were established that the person, who had attempted suicide, did so being 'in his right mind', he had to make his confession in church. The amount of the penalty was determined by religious authorities, in the case of Catholics - by the diocesean consistories of Vilnius or Samogitia. The examination of the person's psychiatric status was carried out by the Medical Department. ${ }^{7}$ In Russia the establishment of such departments began in the late eighteenth century. However, initially, they supervised the running of military hospitals, the observation of quarantine rules, etc. Occasionally they performed the function of forensic medical examiners. The establishment of motives for suicide was becoming the competence of civil authorities.

Since the early years of the nineteenth century various new decrees and regulations on establishing the psychiatric state of the deceased and the causes of their death started to appear. The Senate issued a decree, requiring the participation of a doctor at the examination of a suicide. It forbade burial of the dead before medical examination. ${ }^{8}$ In 1815 the Senate issued one more decree, obliging the physicians of the Medical Department to conduct the psychiatric examination of attempted suicides. That procedure was confirmed by later regulations as well, e.g., in 1842 . However, even then the psychiatric state was often examined only by police or court officials.' Despite the government's efforts to introduce medical examination of

${ }^{7}$ Svod Zakonov Rossiiskoi Imperii. T. 15. Zakony Ugolovnyc. St. Petersburg, 1857, 509-600.

${ }^{8}$ The report of the Lower Zemstvo Court of Ašmena to the Department of Vilnius Province, 29 December 1827, VIA, f. 381, ap. 24, b. 6699, 1. 1.

"Examination report of boyar Adamovičius of 6 June 1832. VIA, f. 381, ap. 24, b. 9099, I. 1-2; decision of the Department of Vilnius Province of 28 April 1849. VIA, f. 381, ap. 19, b. 5128, I. 3 . 
mentally ill people, this was not practiced universally. Firstly, there were not enough experts. As a rule, the gentry had to undergo a medical examination, especially if the case was associated with the problems of inheritance. Secondly, belief that the competence of the court of law or police official was sufficient was widespread and that a doctor was unnecessary to establish the lunacy of the accused. Even the journal Arkhiv sudebnoi meditsiny $i$ obshchestvennoi gigieny, published by the Ministry of Internal Affairs, conducted a lively discussion in 1866 on whether only a doctor could adequately determine the mental state of a person. The same was the case with establishing the cause of death. The first government regulations concerning the exact determination of the cause of death, issued early at the beginning of the century, were repeated several times. On 14 July 1828 one more Senate decree was adopted obliging doctors to determine the cause of death as accurately as possible, as they often failed to do that. ${ }^{10}$

Descriptions of similar regulations could be continued ad infinitum, and their irregular renewal confirms the supposition that at least in the first half of the century they were not put into practice. The question only arises as to what modifications the official attitude towards suicides underwent in the course of time. Without any doubt they were influenced by the theories and social practices coming from Western Europe. Again there remains one more question: why did those influences become apparent in Lithuanian society around the middle of the nineteenth century?

It is common knowledge that government attitudes towards suicide developed under the prolonged influence of Canon law, in which a negative stance dominated the issue as it did on certain other forms of deviant subculture. And it was insanity (as well as minority) that was considered a mitigating circumstance with respect to suicide. Therefore the determination of the psychiatric state of the self-murderer was the main concern of the authorities. Experts - medical workers had to be entrusted with the performance of that task. That was a natural course of events in the early-nineteenth-century Russia, which was developing into a rational, bureaucratic absolutist empire. It must also be noticed that the bureaucratic unification trends intensified in the 1820 s and 1850 s during the reign of Nicholas I. ${ }^{11}$

Although the authorities in various ways encouraged the formation of the social status of psychiatric experts and insisted that they participated in the investigation of suicide cases, practically no attention was paid to the care of the mentally ill until the middle of the century. They continued to be cared for by monasteries and almshouses, which also accepted physically handicapped people; mentally ill repre-

${ }^{10}$ The report of the Ministry of Internal Affairs to the Governor of Vilnius of $28 \mathrm{Au}-$ gust 1828. LVIA, f. 381, ap. 24, b. 7288, 1. 2.

${ }^{11}$ H. Scton-Watson. Russian Empire, Oxford, 1989. 
sentatives of the gentry were looked after by their relatives. In the 1830 s there were two lunatic asylums (for about 30 persons) in Samogitia - in Varniai and in Kenstaičiai, both under the aegis of the Rochites. $^{12}$ Their founders were the Samogitian bishop Melchioras Giedraitis and a landowner, Antanas Rimgaila. The Russian authorities did not interfere in their activities in any way - their only requirement was to send all 'patients' to the monastery hospitals. ${ }^{13}$ A similar 'hospital' was established at the Boni Fratres monastery in Vilnius (it functioned already in 1828). The civil authorities appointed their supervisor and doctor. Those who attempted to commit suicide and were considered 'mentally insane' or 'slightly mentally deranged' were 'confined' there until full recovery. ${ }^{14}$ The main task of those 'hospitals' was to isolate the mentally ill, in particular those who were potentially dangerous to society. ${ }^{15}$

The need for a central hospital ('a regional lunatic asylum') was first discussed only in the $1860 \mathrm{~s}$. The governor of Vilnius maintained that such a hospital could accept about 150 patients, including those from the provinces of Grodno and Kaunas. The initial proposal was to adapt the premises of the Vincentian Monastery for that purpose in Vilnius. ${ }^{16}$ It was repeatedly stressed that the new hospital had to meet the requirements of psychiatric science. One of the main conditions of treatment had to be the division of the patients into four categories. Officials ignored those requirements and pointed to the deplorable state of the asylum, insisting on the need to build the hospital without delay. Meanwhile, the Medical Department of the Ministry of Internal Affairs and a specially appointed commission, comprising medical workers, required to heed the main provisions. ${ }^{17}$ Lastly,

${ }^{12}$ W. Gadon. Statystyka Księstwa Źmudskiego, Paryź, 1839, 52.

${ }^{13}$ The letter of the social care committee of Vilnius province to the department of Vilnius province of 10 October 1837. LVIA, f. 381, ap. 24, b. 12936, 1. 3. According to this document, there were 88 persons in the two almshouses.

${ }^{14}$ The letter of the Supreme court of Vilnius to the department of the province of 25 October 1828. VIA, f. 381 , ap. 24, b. 7294,1 . 1.

${ }^{15}$ The authorities of the Gardinas province applied to the governor-general of Vilnius with a request to 'incarcerate in a lunatic asylum' a student of the University of Dorpat Stankevičius for making 'various patriotic specches' in the province. He admittedly considcred himself a 'libcralist', maintaining that Russia did not cxist any more and that Poland was re-cstablished up to the river Oder. After a psychiatric expertise he was decmed insanc, and a decision was made to isolate the student, because 'all sorts of people enjoy listening to his speeches', which in the eyes of the authorities seemed 'dangerous'; see a secret letter of the Gardinas governor to the governor-general of Vilnius of 17 May 1854. VIA, f. 378 p/s 1854, b. 71, 1. 1-2.

${ }^{16}$ The letter of the governor of Vilnius to the governor-general of 21 March 1864. VIA, f. 378 b/s 1864 , b. $2389,1.1$.

${ }^{17}$ The letter of the Minister of Internal Affairs to governor-general Aleksandr Potapov of 24 August 1864; the letter of the Ministry of Internal Affairs to the governor-general of 10 December 1864; the letter of the director of the Medical Department to Potapov of 2 Junc 1873. Ibid., 1. 25-26, 1. 31-32, 1. 94-95. 
none of the plans for the Vilnius psychiatric hospital was realized. By the mid-1870s patients were 'treated' in the monastery of the Boni Fratres and in the departments of St. James' and the Jewish hospitals, and in the counties they were simply kept at parish almshouses.

Some nineteenth-century writers noted that contemporary society, especially the common people, treated the mentally ill as "corrupted' by a mysterious or even evil force. Hysterics, melancholy and very often epilepsy were attributed to corruption, too. The attitude and behaviour towards mentally ill were the same as towards the physically handicapped and the beggars. The Church was supposed to take care of them. ${ }^{18}$ True, there also existed a less popular opinion about the mad as the chosen ones, i.e., possessing exceptional powers. It is also worth noting that the 'higher estates' were quite indifferent to the mentally insane. ${ }^{19}$ Researchers indicate that in the seventeenth and eighteenth centuries in Western Europe insanity was identified with bestiality and not considered an illness; accordingly the conduct with regard to the insane was brutal. ${ }^{20}$ In any case, in folk tradition insanity was generally not considered an illness. A tolerant attitude towards insanity and the insane also determined attitudes towards suicides. Judging from the evidence of witnesses, temporary insanity was often considered the cause of the suicide. Until that time the person had been quite 'normal', properly performing his duties. ${ }^{21}$ As a rule, relatives and neighbours presented the suicides as unhappy, poor souls or accidental victims. In everyday life they had been good-natured and amicable..$^{22}$

\section{Possibilities of Suicide Control}

In the political system of Russia the sovereign was the principal guarantor of social order. It was maintained not only by the systems of customs, traditions and religions, but also by the ever-increasing bureaucracy in society, both civilian and military. The power of such a state and its ruler was conditioned by certain decisive factors: the number of its tax-paying subjects and the size of the territory. Therefore, control of birth and death rates became a matter of prime importance. Various governmental institutions were established to fight epidemics and compile birth and death statistics.

${ }^{18} \mathrm{~A}$. Shults. Prezrenic pomeshannykh v Rossii (Contempt for the mad in Russia). Arkhiv sudebnoi meditsiny i obshchestvennoi gigieny, kn. 1, ch. 1, 1865, 1-3.

${ }^{19}$ Ibid., 4

${ }^{20} \mathrm{M}$. Foucault. Madness and Civilization. A History of Insanity in the Age of Reason, Ncw York: Vintagc Books, 1988, 74-75.

${ }^{21}$ The record of witncss questioning of 25 May 1861. VIA, f. 669, ap. 4, b. 253 a , 1. 10.

${ }^{22}$ The report of a Maišiagala police officer to the police superintendent of the second district of Vilnius county. VIA, f. 454, ap. 1, b. 1749, 1. 3-4; the certificate of the police supcrintendent of the sccond district of Vilnius county of 20 July 1861 . VIA, f. 454, ap. 1, b. $1528,1.12$. 
With rational bureaucratic trends in the management of social order gaining a foothold, the traditional forms of keeping order gradually lost their former importance. Nevertheless, the bureaucratic empire did not manage to eliminate the influence of religion and customs entirely. Therefore, it is little wonder that the decriminalization of suicide coincided with the bureaucratization of the Russian Empire, which was more intensive in the reign of Nicholas I. At the same time the government did not ultimately diminish the role of the Church in the control of suicides.

The court pronounced the person guilty, and the Church authorities (for Catholics it was the consistories of the dioceses of Samogitia or Vilnius, depending on the locality) meted out a punishment. As a rule, those who attempted to commit suicide had to repent. The duration of the repentance varied between several weeks and several months. Accordingly, the person was settled without any state maintenance in the almshouse of a parish, usually under duress with the help of the police. The offender had to attend a religious service and pray, kneeling or lying prostrate, and fast several days a week. Repentance was followed by confession. ${ }^{23}$

In the second half of the nineteenth century that procedure became definitely established. According to the decisions of the consistory, its main purpose was to demonstrate 'the horror of the suicide sin', that entailed eternal damnation; and secular and canon laws prohibited the burial of suicides in consecrated grounds. ${ }^{24}$ By making confession, the sinner could trust God to forgive his trespasses and thus disburden conscience. Having realized his sin, people should attach greater value to their lives, which the Lord alone can give and take. Deliberations such as these can be found in nearly all suicide cases from the diocese of Samogitia.

The dynamics of suicide does not seem to have had any pronounced effect on the official point of view. In the second half of the nineteenth century the number of suicides rose very slowly. The data of the present paper, regrettably, pertain only to the province of Vilnius, reorganized in 1843 and consisting of seven counties: Vilnius, Trakai, Ašmena, Švenčionys, Lyda, Vileika and Dysna. Besides, the data are neither accurate nor comprehensive, and estimates are complicated not only by inexact population data, but also by rather large numbers of unexplained, so-called 'accidental' deaths. For example, of the 285 accidental deaths recorded in 1892 , as many as 135 , i.e., almost a half, remained unexplained. The situation was similar the following year: of 304 recorded deaths 122 remained unexplained. The ratio was al-

${ }^{23}$ An excerpt from the Telšiai Consistory file on peasant Kuzas, 25 January 1862. VIA, f. 669, ap. 4, b. 253a, 1. 14. Similar files are quite numerous.

${ }^{24}$ The consistory verdict on peasant Aidukas of 15 May 1870 . VIA, f. 669, ap. 4, b. 992, 1. 3-4; the consistory verdict on townsman Naudžiūnas. VIA, f. 669, ap. 4, b. 879, 1. 8-9. 
most the same in 1895 - 289: 124. True, it changed in 1896, 238: 79.25 There may have been suicides among unexplained deaths. It is also not clear whether military suicides were entered into these records.

Table 1

\begin{tabular}{|l|c|}
\hline \multicolumn{2}{|c|}{ Suicide Dynamics in the Province of Vilnius in $1850-1896$} \\
\hline Year & Number of suicides per 100,000 people \\
\hline $1850-1857$ & 2.2 \\
$1860-1869$ & 2.5 \\
$1871-1876$ & 3.2 \\
$1880-1889$ & 4.1 \\
$1890-1896$ & 4.3 \\
\hline
\end{tabular}

The Table is compiled on the basis of the data of the statistical committee of Vilnius province. In the archive all the files are grouped under a common title 'On violent and accidental deaths'. VIA, f. 388, ap. 1, b. 510 ; b. 538 ; b. 565 ; b. 640 ; b. 732 ; b. 751 ; b. 756 ; b. 786 ; b. 805 ; b. 823 ; b. 868 ; b. 889 ; b. 925 ; b. 942 ; b. 964 ; b. 985 ; b. 1002 ; b. 1025 . Data for the years 1850 - 1857 and 1860 - 1869 are taken from the yearly reports of the governor of Vilnius, see f. 388, ap. 1, b. 211; b. 227; b. 242; b. 267(1); b. 288(1); b. 298(1); b. 315; b. 316(1); b. 337(1); b. 359(1); b. $380 ;$ b. 481 .

Thus, with certain reservations, it could be maintained that the number of suicides increased insignificantly only at the very end of the nineteenth century. Data for the second half of the nineteenth century indicate an increase of suicides in the spring and summer months. More suicides were recorded among elderly people. Naturally, there were also more suicides in the counties than in the cities, as more people lived in the countryside than in the towns. Among the latter, Vilnius occupied first place as the largest city in the province.

This analysis can lead only to tentative conclusions due to the absence of empirical data. Using the term of the French sociologist Emile Durkheim, it could be stated that the predominating type was 'the fatalistic suicide'. Its cause was an excessive and exaggerated regulation and suppression of the needs and emotions of the individual by means of 'despotic discipline', as well as the absence of any real prospects for the future. The situation seems not to have changed greatly in the second half of the century. Therefore it is hardly possible to

${ }^{25}$ The data are taken from the reports 'Apic smurtines ir atsitiktines mirtis'/1892-1896, sec VIA, f. 388, ap. 1, b. 942, 1. 1-2, 27-28, 53, 104; b. 964(1), 1. 7-8, 33-34, 56-57, 82-83, 110-111; b. 985 , l. 1-2, 27-28, 53-54, 79-80, 10()-101; b. 1002, 1. 1-2, 87-88, 137-138, $112-$ 113 ; b. $1025(2)$, l. $1-2$. 
speak about the appearance of the 'anonymous' and 'egoistic' types of suicide. According to Durkheim, the latter are found in those societies and social groups, in which the individuals are insufficiently integrated or when the control functions of the community are weakened. Under such conditions the former traditional norms of social behaviour are no more sufficient, 'outdated', while the new communities are not yet strong enough and seem unreliable. In such periods the alienation from the community, the perception of the crisis of 'collective' values ultimately have to do with the increase of anonymous suicides.

The factors that could have affected the formation of anonymity in Lithuanian public life became evident rather late, and relatively they were weak. In other words, industrialization, urban development and secularization proceeded comparatively slowly, and their effect on the disintegration and transformation of the social order, based on traditional moral values, was limited. Vytautas Merkys maintained that even in the second half of the nineteenth century there were no large industrial centres in Lithuania. Their formation began rather late, ca. 1870 - 80, and it was only at the very beginning of the twentieth century that much of the workforce engaged in industry were no longer (or only partially) associated with agriculture. ${ }^{26}$ On the other hand, the population 'explosion', slow urbanization and industrialization caused the growth of Lithuanian emigration. ${ }^{27}$

A relatively small number of suicides could also be accounted for by the repressive religious system, comprising both the negative attitude towards suicide and the sacralization of death, peculiar to religious thinking, prevalent in public life. Death was considered an important phase in passing from temporary to eternal life. Only a good death could ensure such a prospect. It is worth noting that namely at the end of the eighteenth century and in the nineteenth century attempts were made for the realization of that precept, when the Church introduced a stricter control of burial procedures.

Several trends can be distinguished in the religious interpretation of suicide in the nineteenth century. There is no doubt that in general the negative attitude predominated, in which, nevertheless, certain nuances could be detected. Christianity as well as Judaism treated suicide as disobedience to God's will, and hence immoral and reprehensible. Persons, who 'consciously destroyed themselves', were threatened with excommunication from the Church and separation from society. Burial rites also had to demonstrate society's contempt. Suicide was justified only in some exceptional instances, e.g., in the case of a girl, protecting her virginity.

${ }^{26} \mathrm{~V}$. Mcrkys. Razvitie promyshlennosti i formirovanie proletariata Litvy $v 19 \mathrm{v}$. Vilnius: Mintis, 1969, 422-425.

${ }^{27}$ A. Eidintas. Lietuviu kolumbai. Vilnius: Mintis, 1993, 12. 
In the early nineteenth century the subject of suicide was dealt with by Fr. Jurgis Pabrèža. In his sermon on the Fifth Commandment, 'Thou shalt not kill', he stated that it was beyond a sin not only to kill others but also oneself. Committing suicide was a terrible crime. ${ }^{28}$ All suicides, if they "did that in their right mind ... " would not save their souls, all of them would be damned, no matter whether they committed that sin whilst being free or imprisoned; they will be sent in hell. Pabréža's reasoning shows his perception of suicide. Suicides are those who (1) 'burn', freeze to death on the road or drown of hard drinking; (2) fall ill due to bad feeding habits; (3) fall ill of anger, envy, sorrow and die; (4) torture their bodies and thus fall ill; (5) are too stingy to hire a workman, work hard and therefore fall ill; (6) are overzealous in their studies and can commit a sin; (7) spend stingily on clothes, fall ill and die; (8) dress up in winter to look smart, fall ill and die. ${ }^{29}$ That was an all-embracing perception of suicide, comprising both conscious and unconscious suicides. It should be stressed that Pabrěža's concept was not accidental - the intention of this preacher was to protect his parishioners from bad death, thus granting them a chance of eternal life. On the other hand, Pabréža's reflections showed that at that time the peasant did not associate the indicated evils with suicide or sin.

As a rule, only conscious suicide was treated as a mortal sin by the Catholic Church. In a catechism published in Vilnius at the turn of the nineteenth century, its author, the divine, Andrziej Pohl (17421820), also renowned as the author of a famous textbook of moral theology, listed conscious (Pol. umyślne) suicide among other sins against the Holy Spirit and 'crying to Heaven for rengenance'. Suicide was placed at the head of the list of sins, followed by 'the sin against the flesh', oppression of the poor and orphans and failing to pay the servants and workers in time..$^{30}$

A similar scale of values could be found in the middle of the century. The Dominican friar Rapolas Jasikevičius (1801-1879) discussed the six sins against the Holy Ghost and the four 'which cry out to God for vengeance.' Again 'conscious killing' was placed first, followed by 'the sin against the flesh'.31

In religious thinking, there also existed a parallel, more tolerant attitude towards suicides. St. Paul stated that "... to die, and to be with Christ ... is far better". ${ }^{2}$ The answer to a question in a mid-eigh-

${ }^{28} \mathrm{~J}$. A. Pabrěža. Kninga pyrma apey sakramentus ógolnay yr apey nekórius sakramentus ipatingai. Manuscript Department of Vilnius University Library (hereafter VUB RS), f. 1 D $57,1.489,494$.

${ }^{29}$ Ibid., 494.

${ }^{30}$ A. Pohl. Powinnosci chrezescianslie czyli katekizm missyiny. Wilno, 1801, 30.

${ }^{3 !}$ R. Jasikcvičius. Prideristes Krykścioniśzkos parkłausimus yr atsakimus dit parapionu. Wilniujc, 1801, 24.

32Phil., i:23. 
teenth-century catechism "Is it appropriate to wish oneself dead?" was: no, if it was due to despair or anger. However, one could wish oneself dead in order to get to heaven sooner. It was also stressed that "to kill oneself" was "a grave sin and that such a sinner would go with Judas directly to the ever-burning hell". ${ }^{33}$ In his book Broma atwierta ing wiecznasti (first published in 1753; the last - eighteenth - edition in 1851), Mykolas Olševskis (Michal Olszewski)(1712-1779), a Canon Regular and divine, also dealt with the same issues. One could wish oneself death, however, on condition that it was a wish to see 'God's face' sooner. That could not be done due to misfortune or illness. Those who had no patience and 'asked for the death to come' did not realize that that would evoke still greater torments. At the same the answer to the question whether it was possible to bury 'in a holy place' a person who committed suicide due to a severe disease time was positive. Again it was important that that person had to have lived the life of a Christian before his death and 'had gone mad' at the time of death. Accordingly, such a suicide had to have been unconscious. Olševskis indicated some more conditions: those persons had to have gone to their Easter confession and the Holy Communion. ${ }^{34}$ Similar considerations could be found in some other catechisms of the nineteenth century. ${ }^{35}$

All those directives recorded in catechisms, the most popular and widespread books read by common people, had a definite normative purpose. As there always existed a distance between the social norm and particular types of behaviour, it is logical to ask what factors determined that distance, and in the context of the present study to examine the attitudes towards suicide and their evolution in society.

\section{The Customary Interpretation of Suicide}

The attitude and behaviour of common people towards suicide can be illustrated by some examples. In 1864 a 30-year-old peasant woman hanged herself in the village of Kvakšiai, in the Maišiagala district of the county of Vilnius. She was buried in secret without informing the authorities. Nevertheless the event became known, and the death aroused the suspicions of the police. The husband said he had found his wife dead when he came home after work. In his words, 'according to the custom' he invited the relatives of his wife and his neighbours, and they buried the suicide woman in the village cemetery. The priest did not attend the funeral. The woman was buried in

${ }^{3}$ [A. Horainas ?]. Pamokslas krikščioniškas Trumpai išgulditas. Wilniuj, 1743, (pages unnumbercd).

${ }^{34} \mathrm{M}$. Olszcwskis. Broma atwierta ing wiecznasti. Wilniuy, 1824, 60-61.

${ }^{35} \mathrm{~J}$. Lechavičius. Nawies krykszcioniszkas katalykyszkas katechizmas arba tykras davadas apej wiera tykieima ... . Wilniuj, 1847, 26. 
a coffin made by her husband. The participation of all the villagers attested to the fact that at least they did not condemn her family. Later, in their statements to the police they said that it was 'her misfortune'. During the interrogation the husband said that they arranged the burial without delay in an attempt 'to avoid interrogation and the inquest of the dead'. Finally the police officials listed the death as suicide due to an illness. An illness of some sort was also mentioned in the evidence of the witnesses. The outcome of the lawsuit was a three-week detention of the husband in custody for burying his wife without informing the police. ${ }^{36}$

There were also other reactions and attitudes. In the section of 'Letters from the Province', the Petersburg newspaper Kraj published a report from the county of Vilnius on the suicide of an 80-year old woman in the village of Antanaičiai in 1891. Her relatives decided to bury her in the cemetery (Pol. cmentarz, which means that it must have been a walled and consecrated cemetery). The peasants of the village objected to that decision and prevented the burial in the cemetery and even at the cemetery. The dead woman was buried in a forest. After a few days she was re-buried at the request of her relatives with the help of local authorities in a secluded place in the cemetery. The following day the body was exhumed and drowned in a bog. The police arrested three peasants from the village. The correspondent of the report finally remarked that allegedly there was a superstition among the Lithuanians that suicides should be buried further from the residential area, and it was best to drown them, since otherwise their souls wandered all over the world doing their evil deeds. ${ }^{37}$

The described cases revealed controversial attitudes towards suicide. In the first case neither the suicide itself nor the behaviour of her relatives and neighbours raised any objections - fearing the interference of the authorities they hastened to bury the dead in the unconsecrated village burial site, in a way commiserating with the family of the diseased. In the second case the reaction of the village was quite opposite: they prevented the burial of the self-murderer in the cemetery, even opposing the orders of the authorities. In the first case the peasants buried the suicide in an unconsecrated village cemetery - in the nineteenth-century Lithuania such cemeteries could still be found in many places, though burial in them was restricted. Mostly they were meant for those corpses, which could not be buried in consecrated cemeteries. In the second case an attempt was made to bury a suicide in a consecrated cemetery, and that apparently caused great dissatisfaction and anger on the part of the villagers.

${ }^{36}$ The report of the Maišiagala police official to the superintendent of the 2nd district of Vilnius county of 16 May 1864; sce also an cxtract from the case on Pranciška Kvašienè's death, investigated at Vilnius county court, 25 April 1866; VIA, f. 454, ap. 1, I. 1-2, 22-23.

${ }^{37}[?]$. 'Listy z prowincji', Kraj, nr. 5, 1891. 
The difference in the reaction and behaviour of the peasants can be interpreted in a variety of ways. The negative attitude towards suicide in the consciousness of the lower social strata could have been changing gradually under the influence of the religious system, ousting the traditional 'indifference towards death' (both events recorded in the same county, were divided by three decades). Such interpretation would lead to the conclusion that the negative attitude to suicide was not so old as has often been maintained. However, opposite considerations are also possible. Contrasting attitudes and value systems often do not replace each other, they can exist side by side. It can also be maintained that the attention to death and intolerance to unhappy deaths, including suicides, increased when a stricter social convention became established to bury the dead only in consecrated and carefully looked-after cemeteries. The prohibition of the Church and secular authorities to bury anywhere and the control of the burial order led to the formation of a negative attitude towards self-murderers and suicides. They were denied the possibility of being buried with other members of the community and thus they were censured. Doubtless, the new order did not take root overnight.

\section{Attention to Death}

Nothing can demonstrate a new feeling for death more vividly than the attitude to cemeteries. At the end of the eighteenth century it was already thought that cemeteries and their maintenance were to perform significant educational functions. The bishop of Vilnius Jonas Nepomukas Korvin-Kossakovskis in his sermon during the consecration of the cemetery of St. Stephen in Vilnius in 1795 called on all the people to come to the cemetery more often, because many examples of good and moral behaviour can be found there. ${ }^{38}$ The bishop also chided those who wanted to be buried in churches or next to them. In his opinion, 'from time immemorial' cemeteries had been farther away from the living and cities, and exceptions could be provided only as meritorious rewards for service to society.

The Russian authorities also introduced stricter control on burials. The first decrees regulating them were issued in the early eighteenth century. Local authorities were instructed to set up cemeteries farther away from the settlements, burials in residential areas were forbidden, burial in churchyards was restricted, etc.. An imperial decree of 1818 required 'not to have' cemeteries in the settlements, and instead sites had to be found for new cemeteries outside at a greater distance. ${ }^{39}$ Similar tendencies were observed in Western Europe as

${ }^{38}$ Kazania świąteczne i przygodne z rękopisów, Wilnic. 1824, 438.

${ }^{39}$ Polnoe sobranie zakonov Rossiiskoi Imperii. Sankt-Petcrburg. T. 35, nr. 2781, 1830, 621-622. 
well. In the words of Philippe Ariès, cemeteries were no longer left 'at the mercy of nature', people began taking care of them. In his opinion, there were two reasons (sanitary and moral) for that: (1) the fear of epidemics, and (2) 'a shame to bury human beings like beasts'.

People, however, were inclined to retain their old customs. Thus, the lower zemstvo court of law of Ukmerge complained that the rector of Svedasai parish buried the dead in the church and in its graveyard, and he continued to act in the same manner despite the admonitions of police officials, "thus encouraging popular disobedience". ${ }^{40}$ After a few days the governor sent a circular issued by the Russian Ministry of Internal Affairs, explaining the burial requirements. It stressed the need to inter the corpse in a grave as deep as possible in winter (at least a metre and a half), because the authorities had received information that in spring the bones of the dead appeared on the surface of the grave, and this was fraught with epidemics. ${ }^{41}$ After some more days Bishop Korvin-Kossakovskis in his letter to the priests forbade to bury in churches and to limit burials in their graveyards. Nevertheless, even later the new order often was a source of misunderstanding. Sometimes parish priests ignored the regulations of secular authorities and refused to bury the dead in the newly appointed burial sites. For example, the police superintendent of Ukmerge informed the governor of Vilnius, Horn, that the rector of Utena had buried a landowner at the church instead of the cemetery outside the town. ${ }^{42}$ The Roman Catholic consistory of Vilnius explained that that burial did not entail any violation of the regulations. The deceased was buried in the 'old' cemetery of Utena which was over 25 years old and was also located outside the town. ${ }^{43}$

The sacrality of the cemeteries and the need to look after them were often emphasized in many nineteenth-century texts. The Dominican, Rapolas Jasikevičius, stressed the holiness of burial sites and maintained that "...this place is acquired at the price of the sufferings and death on the cross of the Saviour." According to the preacher, Christ himself blessed the first graveyards with his blood. ${ }^{44}$ They were places where one had to behave piously, not to drink. Cemeteries should be kept in good order and enclosed to keep animals away. In one of his sermons in 1813 Jurgis Pabréža stated that good Christians and de-

4The letter of the lower zemstvo lawcourt to governor-gencral Rimskii-Korsakov of 21 March 1808. VIA, f. 378, b/s, 1808, b. 85, 1. 1-2.

${ }^{4}$ The circular Ietter of the Ministry of Internal Affairs to the governors of 26 March $1808,1.7$.

${ }^{42}$ The report of the zemstvo superintendent of Ukmerge of 23 December 1827. VIA, f. 381 , ap. 24, b. $693($ ), 1. 2.

${ }^{43}$ The letter of the Roman Catholic Consistory of Vilnius to the board of Vilnius province of 30 September 1829, 1. 9.

${ }^{4} \mathrm{R}$. Jasikcvičius. Pamoksłay unt nekuriu szwincziu, unt atminimu aźu numirusius, prieg paszwintinimu križiu, kapu, namu, dyrwu. Wilniuje, d. 3, 1859, 30. 
vout people had to be buried 'in holy sites', and they could not be buried in the fields or 'bushes'. ${ }^{45}$ Similar opinions were frequent at the end of the century as well. In Kazimieras Pakalniškis words, the bodies of those who had lived pious lives, had to be buried 'in holy sites'. He also indicated who could not be buried in such cemeteries. The first group comprised the so-called 'unbaptized', i.e., Jews, heathens, unchristened children, excommunicates, heretics who openly propagate their views, schismatics or 'Muscovites', and finally 'dissenters' - atheists, 'materialists', 'rationalists', i.e., those who reject divine revelation. The second group consisted of Catholic sinners, who due to their evil deeds remained 'Catholic only in name'. Among them were 'duellists' (possibly those killed in brawls without being to confession were meant), various 'open' sinners, who 'met their end' without having been to Easter confession. And the last group were suicides, those 'who put an end to their own life of their own free will'. ${ }^{46}$ The violation of burial regulations would desecrate 'the holy place', and as long as the corpse of the suicide was not exhumed and removed from the cemetery, burying would be impossible there. The cemetery itself had to be re-consecrated. The article ended on a sad note: corrupt officials did not always observe the established order.

In the nineteenth century the cemetery became a source of poetic inspiration. At the beginning of the century a poet, hardly known to anybody today, was glad that the graves were visited and looked after by the relatives and friends of the dead, and that inspired the following couplet: "Let's shake hands as brothers / And pledge always help others / ..." ${ }^{47}$ The cemetery could give rise to the feelings of both sorrow and mourning and of particular unity and solidarity. Writers often idealized the atmosphere of the cemetery. A visitor could be captivated by even an ordinary, not well looked-after village cemetery as an object of deeper experiences. Andrzej Jastrembski described a cemetery of the church of Paželvè, deanery of Ukmergè, Kaunas province in this way. There were no marble monuments there, because only 'poor peasants' were buried there, on whose graves 'the grass grew freely and lovely'. The writer remarked with admiration that the Lithuanians would sooner forget to take care of themselves than of their relatives. ${ }^{48}$ According to contemporary accounts the inhabitants

45J. A. Pabrčža. Op. cit., 1. 350.

${ }^{46}$ P. Zuikis [K. Pakalniškis]. Ka galima, o ko negalima laidoti ant kapų (Who can and who cannot be buricd in a cometcry). Žemaičiy ir Lietuvos Apžvalga, nr. 22, Deccmber 1890 .

${ }^{47}$ J. Reyzner. Cmentarz (Cemetcry). Tygodnik Wileński, t. 6, nr. 122, 1858, 401.

${ }^{48}$ A. Jastrembski. O koscicle w Pozelwic (About the church of Pažclvè). Teka Wileńska, nr. $5,1858,401$. 
of Vilnius used to spend their leisure visiting the graves of prominent people in the cemetery of Rasos. ${ }^{49}$

It can be surmised that namely in the first half of the nineteenth century people began paying much attention to the maintenance and care of the cemetery. Both religious and secular authorities were interested in that, and efforts were made to cultivate the respect for the cemetery as a social value and norm. The peasants, however, still continued to bury their dead without confessions and priests in unconsecrated village cemeteries. The Church and civil authorities treated that with discontent, however, it is not known what measures were taken to prevent that practice..$^{50}$

In the countryside burial practices changed very slowly in people's consciousness. ${ }^{51}$ In his study on the history of culture Apie senovines pagoniškas religines apeigas Lietuvos ir Žemaičiu kunigaikšsijose (1823) Dionizas Poška made no mention about the custom among peasants to take care of the cemeteries. True, paying tribute to the dead was practiced there since days of old. In Samogitia the funeral customs comprised the burial dinner. According to Poška such meals were often held in the cemeteries as late as the turn of the eighteenth and nineteenth centuries, and the Church persistently fought against that custom..$^{52}$ It seems that at that time the peasants were more interested in possible dangers emanating from the souls of the dead than in the tribute to them. Funerals in unconsecrated, not properly looked-after places were still frequent. In his 1853 memoirs Vladislavas Sirokomle (Władisław Syrokomle) indicated that the peasant cemeteries were close to their homes, however, they were not looked after. ${ }^{53}$ Accordingly the dead were soon forgotten. In a similar manner a village cemetery was described by Adam Mickiewizc in his poem Pan Tadeusz:

Na dziedzińcu spomiędzy piołunu i chwastu

Wznoszą się stare szczęty krzyżów kilkunastu

${ }^{4 T} T$. Krasiński. Dziennik ucznia Uniwersytctu Wilcńskicgo (1816-1818): H. Mońcicki. Z filareckiego świata. Zbiór wspomnień z lat 1816-1818, Warszawa, 1924, 43.

${ }^{5}$ The letter of the head of the gendarmery board of Minsk province to the governorgencral of 27 May 1870. VIA, f. 378, p/s, 1870, b. 115, 1. 1.

${ }^{51}$ The ethnographer Angelè Vyšniauskaite considered that in the nineteenth century "Lithuanian peasants did not pay any particular attention to their cemeteries, except on All Souls' Day (Vélinès)"; sec A. Vyšniauskaitė. Laidotuvių papročiai Lietuvoje XIX a. XX a. pirmaisiais dešimtmečiais . Iš lietuviॄ kultūros istorijos, Vilnius, 1961, 154.

${ }^{52} \mathrm{D}$. Poška. Raštai. Vilnius: Valstybinć grožinc̀s literatūros leidykla, 1959, 379-387.

${ }^{53} \mathrm{~W}$. Syrokomlc. Wendrówki po moich niegdyś okolicach. Wspomnienia, studja historiczne i obyczajowe. Wilno, 1853, 225, 238. 
Na ziemi nieświęconej; znak, że tu chowano

Poległych śmiercią naglą i niespodziewaną. ${ }^{54}$

(In the yard, among the weeds and the wormwood, rose the old stumps of some dozen crosses on unconsecrated ground, a sign that here lay buried men who had perished by a sudden and unexpected death. $)^{55}$

The suicides were also attributed to those 'who perished by a sudden and unexpected death'. True, this short extract shows that those cemeteries were intended for those who for various reasons could not be buried in consecrated sites.

There were no institutions to control burials in unconsecrated 'village cemeteries', and no care was taken of them. Today it is difficult to establish even their exact number, which undoubtedly must have been much greater than that of consecrated cemeteries. In the 1782 visitation-records from the Kaunas deanery two types of cemeteries were mentioned: (1) consecrated ones (cmentarz) at the parish churches (also referred to as churchyards), usually surrounded by a stone wall and looked after, and (2) mogila, usually unconsecrated, not looked after and even not enclosed. Thus in the parish of Kaunas there were 15 'unenclosed' cemeteries on the other side of the Nemunas, 8 - on the other side of the Neris, and 6 more - between the Nemunas and the Neris; the indicated numbers greatly exceeded those of the enclosed burial places. ${ }^{56}$ In the parish of Jieznas there were two main cemeteries - one at the parish church, surrounded by a stone wall, and the other - farther away, 'in an open field', a fenced enclosure. All the other burial places were neglected, nonetheless people continued to bury their dead there. ${ }^{57}$ It was also noticed that people were getting used (to be precise, they were accustomed) to burying in the cemeteries at the parish churches. ${ }^{58}$ In some parishes, e.g., in Švenčionys, the so-called mogilz, nevertheless, were still numerous. Actually they were at each village, unconsecrated, not enclosed and not looked after. The situation was similar in the parish of Taurage. Sometimes such cemeteries were surrounded by wooden fences 'to keep out the animals'."

In the middle of the nineteenth century the differences between the two types of cemeteries seemed to have been disappearing as regards sacredness and social prestige. That was mainly due to the improvement of the status of the mogilz, in which in the course of time

\footnotetext{
${ }^{54}$ A. Mickicwicz. Pan Tadeusz. Bibliotcka Narodowa, scr. 1. Wroclaw-WarszawaKraków, 1994, 313.

${ }^{55}$ A. Mickicwicz. Pan Tadeusz. Transl. from the Polish by G. R. Noyes. London and Toronto, 1930, 169.

${ }^{56}$ Parish church inspection records of Kaunas dcancry. VIA, f. 694, ap. 1, 1. 62.

Thanks are due to the Samogitian historian Vytautas Jogela for the permission to use his manuscript.

${ }^{57}$ Ibid., l. 74-75, 85.

${ }^{58}$ Ibid., l. 102, 270.

${ }^{50}$ Ibid., I. 112, 219, 290.
} 
the majority of the dead were buried. The records of the registry office mentioned 'private' and 'public parish' cemeteries of that kind. They were usually described as being outside a town or village, and burials there were attended by a priest. ${ }^{60}$ The registry records of the 1860s simply stated that the dead were buried mostly in the "parish cemeteries'. True, a peasant could also be buried in the 'local village cemetery', but already in the presence of a priest.

On various occasions, reiterating the prohibition on burying the sinners (including the suicides) together with pious Christians could be relevant only in case of the burials in consecrated cemeteries. Otherwise the prohibition of that sort would have been senseless. Such a prohibition could become meaningful only with the disappearance of the tradition to bury in unconsecrated neglected mogily and with the restriction of such burials by all possible means, at the same time fostering a new sense of respect to the cemeteries. On the other hand, the establishment of new 'public' cemeteries provided a possibility for all the layers of society, regardless of estate or wealth, to be buried 'on holy grounds'.

In addition to cemeteries, greater attention was being paid to funeral rituals as well. Traditional burial customs came in for criticism. In the sermons people were urged to concentrate more on spiritual matters rather than on less significant rite attributes. Those suggestions in the first place were meant for common people.

In the above-mentioned sermon of 1813 Jurgis Pabréža stated that the main purpose of the funeral was 'to help the soul of the deceased' to go to heaven. People should be interested not in the funeral meals, but in the aid to the dead person's soul. Certainly, those who came to the funeral had to be fed, but only in order to keep vigil and pray for the deceased. According to the preacher, the refreshment table had to help those attending the funeral to pray to God to relieve the dead of 'the sufferings in the Purgatory'. Candles were lit in order to make the living save the soul of the dead, since they themselves were already helpless. Therefore solemn funerals were to be avoided, because they only gave pleasure to the living and were of no avail to the dead. ${ }^{61}$ Pabrěža also accentuated the necessity of deeper experiences rather than outward effects: during the funeral weeping was possible, however, it could not interfere with the prayers. A similar viewpoint was expressed by a mid-nineteenth century preacher: Christians should 'always be temperate in lamenting and weeping', because

${ }^{(x)}$ Registry certificatcs of the deaths in the Samogitian Roman Catholic diocesc of Tclšiai in 1831, chast' 1 . VIA, f. 669 , ap. 1, b. 669, p. 18, 23, 28, 314-320; Registry certificates of the funcrals in the parish church of Kaunas in 1845. VIA, f. 669, ap. 13, b. 22, 1. 81, 134-138.

${ }^{61} \mathrm{~J}$. A. Pabrěza. Kninga pyrma apey sakramentus ógolnay yr apey nekórius sakramentus ipatingai.Manuscript Department of Vilnius University Library, f. 1 D 57, 1. 350-351. 
the deceased 'obtained life instead of death'. ${ }^{62}$ In his Büdas senoves lietuvių, kalnènu ir žemaičiu the Lithuanian historian Simonas Daukantas wrote that the main aim of the relatives and neighbours, assembled for the wake (budyne) at the dead, was to help the souls 'to find peace' as soon as possible. ${ }^{6.3}$

Regrettably, things were different in practice. According to Pabrèža, people often attended the funerals to have a chance to drink and to eat. Under the influence of vodka young men and maids lounged about, committing the most ugly sins. Others did not pray, they just slandered the deceased. Still others, being tipsy, drowsed or talked indecently. Even the singers recited prayers and sang hymns only 'in order to get a glass of vodka'. Few people sincerely prayed for the deceased - this was a sad conclusion of the preacher. ${ }^{64} \mathrm{~A}$ similar description of a community vigil was made by Ignas Končius: "Among those who assemble for the vigil there are such who use the occasion to get a substantial meal, since good food is served then. A one or twoyear-old calf or a couple of sheep are usually slaughtered - there must not be any shortage of food. Cakes are baked. ... Beer is brewed (some of it is always kept in store). Cabbage is boiled, and porridge is cooked. There is herb tea galore. Hymn singing goes on without interruption. The principal hymns are the so-called Calvary hymns (Kalnai), sung during the night-time. Various litanies are chanted and all prayers are said ...When some sing, others eat. Then they swap ower". ${ }^{65}$ However, it is difficult to believe that at the start of the nineteenth century and even in the middle, when famine and bad harvests were frequent, feasts of such proportions could be held. It is quite probable that the criticism of unbecoming behaviour was sometimes exaggerated to a certain extent. Some remarks, nevertheless, were not quite out of the place. In the nineteenth century the campaign for 'the religious purity' of funeral rituals intensified. On the other hand, a good, honourable death was treated as a community matter, uniting the living, who had to provide help to the soul of the deceased to go to heaven.

Examples of 'genuine religiousness' and tribute for the deceased could be the accounts of the funerals of prominent people who had been known for their 'honest life'. This was how Motiejus Valančius and Feliksas Praniauskas described the funeral of the Samogitian bishop Juozapas Arnulfas Giedraitis in 1838. After death the body of the bishop was anointed with precious oils, i.e., embalmed and 'dried' in Alsèdžiai for a month. The Chapter had to obtain a permission from the Russian authorities for the burial in the cathedral of Varniai, and Canon

${ }^{62}[$ ?]. Pamokslay ir kozones ape smerti ant uźiwojma prieg pagrabam ir del palinksminima uźsmutitu. Mintaujoj, 1864, 3.

${ }^{63}$ S. Daukantas. Raštai. Vilnius: Vaga, 1976,t. 1, 551-557.

${ }^{64}$ J. A. Pabrčža. Op. cit., 1. 353-354.

${ }^{65}$ I. Končius. Žemaičio šnekos. NIDA Press, 1961, 139. 
Juozapas Rupeika applied to the governor-general Nikolai Dolgorukov for the sanction to bury the bishop in the church. ${ }^{66}$ Dolgorukov agreed and informed the Ministry of Internal Affairs about the burial. The letter of the Ministry stated that the laws did not prohibit the burials in the crypts, which for many years was 'meant for Samogitian bishops'. The same letter also. repeated the general requirement to bury the dead farther from the settlements in the so-called 'public cemeteries'. ${ }^{67}$ The burial ritual started in the church of Alsedžiai with a splendid sermon, delivered to the assembled crowds, when the remains of the deceased were taken from the church. The coffin was brought to Telšiai for a vigil and Holy Mass in the Bernardine church. From there the procession proceeded to Varniai. According to police reports a crowd of about 5,000 strong accompanied the remains of the bishop from Telšiai to Varniai. ${ }^{68}$ At the town the procession was met by 'all prelates, canons and great crowds'. After the funeral Mass the bishop was buried in the cathedral. ${ }^{69}$

Some observations of Fr. Feliksas Praniauskas' are also of interest. ${ }^{70}$ The author singled out the hymn singing of the priests, accompanied by the 'choir' of military music, which greatly moved the people attending the funeral on the first day. The atmosphere of excitement prevailed up to the very end of the funeral ceremony - the bishop was buried 'with everybody grieving and weeping'. All social groups participated in burial procedures. At Telšiai the procession was met by local officials, the gentry (Pol. obywatelstwo), led by the marshal, the pupils of the county school with their class banners, even by the 'Israelites' with candles, and lastly by 'crowds of common people'. The cathedral of Varniai was filled to capacity by the gentry alone, assembled from all the counties of Samogitia. The following remark ended the obituary: "Due to the efforts of the police chiefs, despite the enormous gathering of the people of all estates, classes and religions, the public order ... was kept in the most irreproachable way."

No doubt, the death of a bishop - a religious leader and a moral authority of the community - was an extraordinary event in the public life. A crowd, collectively grieving the death of its pastor, was a significant component of that ritual. In the first place its tribute to the de-

${ }^{66}$ The letter of Canon Juozapas Rupcika to governor-general Dolgorukov of 7 July 1838. VIA, f. 378 , b/s 1838 , b. $20,1.6$.

${ }^{67}$ The letter of the Department of Religious Affairs of the Ministry of Internal Affairs to governor-gencral Dolgorukov of 4 August 1838. Ibid., 1. 8.

${ }^{6}{ }^{6}$ The report of the military chicf of Rasciniai and Telšiai countics to the governorgencral of 11 August 1838. Ibid., 1. 11.

${ }^{69} \mathrm{M}$. Valančius. Raštai, t.2. Žcmaičių vyskupystc் . Vilnius: Vaga, 1972, 187-188.

${ }^{70}$ F. Pranicwski. Nckrolog, xiąż Józcf-Arnolf Gicdroyć Biskup Źmudski (Obituary of the Samogitian Bishop J. A. Gicdroyć). Tygodnyk Peterburski, nr. 66, 23 September (4 October new stylc) 1838 . 
ceased was manifested by the size of the crowd and the intensity of its feelings. The funeral ritual, the carrying of the body from one locality to the other actually meant the involvement of all social layers, the formation of a particular collective feeling, based on deep individual involvement.

A good death was generally associated with both a solemn and orderly funeral procession. Therefore it was not accidental that much attention was paid to the maintenance of order during the funeral, because the crowd consisted of most varied elements of society, from the elite to the paupers. As such 'a mixture of estates' could always be a cause of unrest and social violence, special measures were usually taken to enforce the law. The participation of the police at funerals became quite normal. Nevertheless, the presence of large crowds and excessive demonstration of feelings did not always ensure the necessary order. ${ }^{71}$

\section{Death as Educator and Moralizer}

In the religious world outlook death is a gate through which one must pass in order to go to heaven. Death means a boundary between the two phases of human life. 'After proper preparation' death is not at all menacing or terrible. In the nineteenth century the ritual to prepare for a fair death became established. Sermons were published to teach the people to prepare for a fair and honest death. A typical example of such an instruction was a sermon of Jonas Lechavičius. ${ }^{72}$ The first part of the sermon explains why the dying need the assistance of the living. The dying cannot overcome 'the fear of death' by themselves. It is the most terrible thing, because there is no greater pain than the one experienced when the 'spirit leaves the body'. In such a situation people stop thinking about the salvation of their souls, and they need somebody to help them. There are no naturalistic views of the hell or disintegrating bodies in the writings of that time. The second part of the sermon deals with the preparations when one is confronted with death. Anticipating the approach of death people must settle not only their spiritual but also earthly matters, that is, draw up wills, divide their property, pay back loans, beg their relatives' and neighbours' forgiveness for wrongdoings, inform them about the place of their burial, etc. After that one could think about 'the spiritual matters'.

\footnotetext{
${ }^{71} \mathrm{Sec}$, e.g., the description of the funcral of Mykolas Dluskis, archdeacon of Vilnius Cathedral, a famous mason, in: S. Moravskis. Keleri mano jaunystès metai (Transl. fr. Pol. by R. Griškaitc) . Vilnius: Mintis, 1994, 40.

${ }^{72}$ JJ. Lechavičius]. Prawadnikas ing Tiewiszki dangaus amžina ... Par storoni kuniga K.K.D.J.P.Ł. Wilniuj, 1835, 94. The first publication appeared in 1776, the seventh (and the last) - in 1849.
} 
It is just in the face of the death that a person's 'honour' is revealed most vividly, and one's worth is displayed. Death is not only an important point on the way to eternal life, but also an indicator of one's best and worst traits. Therefore, it is perfectly understandable why a good death is considered an effective educational means: "The moment of death, if only it can be kept permanently in our minds, would be a most perfect school of our praiseworthy customs". ${ }^{73}$ People are advised to think about death more often. A famous nineteenth century Jesuit preacher, Andrzej Filipecki, remarked that thinking about death was necessary and obligatory, since " human beings would not perform the duties, assigned to them, if they did not regularly think about the approach of their death" ${ }^{74}$ In one funeral oration Fr. Tadas Lichodzejauskas wrote: "For us death is the science of life, while sufferings and pains only testify to the greatness of God ...". ${ }^{75}$

The descriptions of 'good death' were numerous in the writings of the late eighteenth and the beginning of the nineteenth century. They almost never touched upon the causes (diseases) of the death, instead their main focus was on the behaviour of the dying, their last words, etc. In his funeral sermon on the death of the wife of the Vitebsk voivode Pranciška Pacienè, Mykolas Karpavičius (Michał Karpowicz) emphasized that before receiving the holy sacraments the deceased managed to bid farewell to her whole family and to ask their forgiveness for any offences she had caused them. Her last words were: "I am not afraid of death, I am ready for it any minute, only, Father, with your blessing help me to behold my Lord". ${ }^{76}$ Count Antanas Tiškevičius, lying on his death-bed, at first said good-bye to his servants and asked to be forgiven. Having received the holy sacraments he bid farewell to his wife and blessed his only son. Finally he asked his confessor and his wife to have his servants and his family properly rewarded. ${ }^{77}$ Fr. Matas Markevičius, ravaged by diseases, threw himself on his knees yearning for holy sacraments before his death. Having pronounced 'Have mercy on me' he passed away 'gently and piously' in the presence of his friends and parishioners. ${ }^{78}$ A good death is public and simple.

Descriptions of model deaths could also be found in newspapers. In 1838 Kuryer Litewski wrote about the death of a distinguished French politician, diplomat, count Charles Talleyrand. He died sur-

${ }^{73}$ Kazania swiateczne i przygodne ..., 372-373.

${ }^{74} \mathrm{Na}$ niedziele calego roku kazania ks. Andrziea Filipeckiego ... . Wilno, t.4, 1842, 46.

${ }^{75}$ T. Lichodzcjauskas. Gailus atminimas tieysinga giwenima kuniga Mateusza Markiewicziaus, klabona baźniczias Birźu ... . Wilniuj, 1841, 13.

${ }^{7}$ Michala Karpowicza Kazanie na pogrzebie ciala swiętey pamięci I.W. IMCI Pani Franciszki z Chaleckich Pocejowy, w Wilnic, [1774], 22-23.

${ }^{7 N} \mathrm{Na}$ pogrzebie swiętey pamięci Antoniego ... hrabi Tyszkiewicza general leytenanta ... Kazanie $x$. Michała Karpowicza. Wilnic, 1779, 1.n.

${ }^{78}$ T. Lichodzicjauskas. Op. cit., 20. 
rounded by his family and friends. Everybody endeavoured to remember his last words. The witness to that event was fascinated by the way Talleyrand anticipated 'the approach of his last minute' and by his adequate preparation to meet it. That was attested by his wills, drawn up in advance, and a conciliatory letter to the Pope. ${ }^{79}$ The premonition of one's demise is one more attribute of a fair death.

The contemporary obituaries described not only the life and merits of the diseased, but also the circumstances of their deaths and funerals. Again the didactic educational function of those writings was quite clear. Their authors deliberately accentuated the social significance of the death. In Teka Wilenska (nr. 2, 1857) Adomas Kirkoras published an obituary of his friend, the chief physician of St Jame's hospital, a member of the Vilnius Archaeological Commission JulionasAlbinas Mošinskis (Moszyński). The description of 'the moment of death' was of particular significance for the author. Being a doctor, Mošinskis realized the imminence of his death and remained calm: when the pains subsided he consoled his wife and friends, and made a will. On his death-bed he was surrounded by his friends, and his home was 'full of visitors'. After death his body was taken to St John's church, and the procession was accompanied by 'a great crowd'. The following day after the holy mass and a sermon he was buried in the cemetery of Rasos in the presence of 'a thousand-strong crowd'.

Burials attended by masses of people were also an indication of a good death. Accordingly the presence of numerous representatives of all social strata was always desirable at the funerals. When Joseph Frank, a professor of the University of Vilnius died in Como, Italy, in 1842, a commemorative funeral service was held in Vilnius. ${ }^{80}$ The newspaper stressed that during the service the church was full of 'pious people', physicians of the city (the members of Vilnius Medical Society came together in their full dress), there were also students, and friends of the deceased.

At the start of the century an important event in the public life of Lithuania was the commemoration of the death of Tadeusz Kościuszko. The national hero died in Switzerland on 15 October 1817. In the months of November and December funeral masses were held, special sermons and speeches were delivered, donations for the poor were collected, etc. Contemporary periodicals wrote at length about the celebration. Additionally, Kuryer Litewski published the speeches and funeral sermons. ${ }^{81}$ Much was said about love of the fatherland and 'genuine patriotism', which also implied the loyalty to the tsar. Homage was paid to both Kościuszko and tsar Alexander I. The prin-

${ }^{79}[?]$. Kuryer Litewski, nr. 42, 27 May 1838,

80[?]. Kuryer Wileniski, nr. 22, 19 March 1843.

${ }^{81}$ Kuryer Litewski, nr. 94, 23 November 1817; nr. 97, 4 December 1817; nr. 102, 21 Decomber 1817; nr. 103, 26 December 1817. 
cipal commemoration was held in St Casimir's church in Vilnius on 10 and 11 December. Prof. Jonas Rustemas designed a special five-tier catafalque, decorated 'with flags and national coats of arms'. The funeral service was held by the Suffragan Bishop Nikodemas Puzinas, the sermon was delivered by the Cathedral preacher Bonaventūra Nosevičius and a eulogy - by Mykolas Römeris, the gentry marshal of the county of Trakai. On the first day of the celebrations the admittance to the church was by invitations, on the second - it was free. The police of the city kept order. Big crowds came to the church to pay their last respects to the deceased.

We may conclude that in literary writings death and burial rituals were presented slightly theatrically. In that respect it should be noticed that at that time it was perhaps the only real and seriously experienced performance. At the mass and in the funeral ceremony the crowd was not just passive extras, but active participants of the event. That socially and ethnically varied crowd was united by a common funeral experience, which, in its turn, had also become more psychologized - more intensive and subtler. Antanas Baranauskas stated that the news about the demise of Bishop Motiejus "simultaneously shocked all the hearts like an electric spark" ${ }^{82}$ That was a strong feeling, disregarding any class or social constraints. At least for a while such experiences transgressed the ethnic and social boundaries, uniting the common people and the elite.

Information about a funeral was spread in various ways: the poor and beggars (who exploited the occasion to solicit alms) learned about it from the toll of church bells, other people received specially prepared invitations. The invitation, issued by the Medical Society of Vilnius on the occasion of Prof. Frank's funeral, contained a small lithograph and a cross in a black frame. It showed a little angel resembling Eros, his right hand covering his face. On the stone pedestal there stood a vase, covered with a black cloth. Both the covered face and the black cloth were to be taken as signs of mourning. ${ }^{83}$ Similarly decorated was the invitation to the funeral Mass and burial of Prof. Jan Wolfgang, except the angel was replaced by a female dressed in a tunic. Leaning against a pedestal, embellished with classical ornaments, the sorrowful woman also covered her face with her right hand. On the opposite side was a picture of a bowed tree. ${ }^{84}$ The lithographs gave

${ }^{82}$ Przemówienic przy złozeniu na katafalku zwłok Ś.p. Kazimierza Wołonczewskiego <..> 20 maja 1875 r. w Kownic przcz Inspcktora Seminarium Księdza Antoniego Baranowskicgo. Lictuvių litcratūros ir tautosakos instituto bibliotckos rankraščių skyrius (Manuscript Department of the Library of the Lithuanian Institute of Language and Folklore, hereafter LLTIB), f. 1-558, I. 3.

${ }^{83}$ Information about the commcmoration of Prof. Jozef Frank's death. VUB RS, 1843, f. 26-191. There are 27 unnumbered copics of the invitation.

${ }^{84}$ Invitation to the funcral Mass for Prof. Jan Wolfgang on 19 May 1859, published by J. Zawadski. VUB RS, f. 26-187, unnumbered shcets. 
the invitations an atmosphere of grief and absorption. According to Ariès, such was the depiction of a 'domesticated' and 'humanized' death, for which there should not be any fear.

Funeral notices usually informed about the person's death, the time when the body was to be taken from his home to the church, where and when the burial was to take place. ${ }^{85}$ They are a good information source for the reconstruction of the 'desired' order of the funeral. A good death should occur in the presence of the family and friends after a corresponding preparation, i.e., after making a will, after receiving the holy sacrament, etc. The corpse was taken to the church in the evening. The funeral Mass and the burial were attended by many people. Not only the relatives and friends were informed about the funeral - messages about it were displayed in the streets of the city, too. ${ }^{86}$ In that way greater numbers of people could be expected at the funeral ceremony. No doubt, not every inhabitant of the city was buried in that way. The invitations to the funerals was part of the social prestige of the deceased, accessible only to the social and cultural elite of the country. In folk culture there was no custom to invite to the funeral. Receiving news of the death was per se an obligation to attend the funeral. ${ }^{87}$

In the second half of the nineteenth century and in particular at its end, the obituaries, the messages about the death and invitations to the funerals became extremely brief. The ornamentation disappeared from the invitations, too, except a black frame and a small cross. On the other hand, they contained more detailed information on the circumstances of the death, the illness, ${ }^{88}$ which became a more significant element in the experience of death.

Funeral sermons always were essential components of burial rituals. In the opinion of the Polish historian Bogdan Rok, those ser-

${ }^{85}$ Invitation to Prof. Michał Homolicki's funcral; 21 January 1861; issued by A. Kirkoras' printing house. VUB RS, f. 26-195, 1. 1. It informed that the body was to be taken from the residence of the deceased in Skapo St. at 6 p.m. on 23 January. The funeral Mass in St John's church and the burial in the cemetery of Rasos had to take place the following day. Similar invitations were issued for the funerals of some other members of the Medical Socicty of Vilnius between 1855 and 1860: Stanisław Rosołowski, Karol Podczaszyński, Prof. Adolf Abicht. VUB RS, f. 26-190, 1. 2-4.

${ }^{86}$ Message about the death of Fiodor Filipov, member of the Medical Society of Vilnius, medical inspector of Vilnius county, on 21 Fcbruary 1875 . VUB RS, f. 26-212, shects unnunbered. The Society spent 29 silver roubles for the funeral: 25 - for the Mass, 3 - for the production of the invitations at Syrkin's printing housc, and 1 rouble - for sticking the messages in public places.

${ }^{87} \mathrm{~A}$. Vyšniauskaitè. Op. cit., 140.

${ }^{88}$ Sec the messages about the deaths of several members of the Medical Socicty of Vilnius in 1895, VUB RS, f. 26-232, 1. 1-5; the 1901 messages, VUB RS, f. 26-239, 1. 1-6; the message about the death and funcral of the chicf physician of the Jewish hospital Lev Geršun in 1897, VUB RS, f. 26-234, lists unnumbered; messages about the deaths and funerals of the members of the Society Ivan Zhitski and Angel Avlosewicz in 1876, VUB RS, f. 26-213, 1. 1-3. 
mons were the most popular genre of funeral writings in the PolishLithuanian Commonwealth. Very often several sermons were delivered during a ceremony, and after the burial they were published. The first sermons were published in the sixteenth century - they had been delivered during the funerals of the rulers. The publication of sermons became especially popular in the second half of the sixteenth and in the seventeenth century. Such sermons usually consisted of three parts: (1) the enumeration of the merits of the dead, (2) the lamentations of the loss, and (3) the consolation of the family of the deceased. ${ }^{89}$ The publication of funeral sermons was continued in the nineteenth as well; after the burial of the Professor of Vilnius University Filip Neriusz Golanski all the eulogies, sermons and obituary were issued even as a separate booklet. ${ }^{90}$ It seems that preserving the former traditional composition the writers started paying greater attention to the first part of the funeral speeches.

In his sermon, delivered at the funeral of Józefa and Woyciech Puslowski (he was the marshal of Slonim county), the Piarist monk Anton Moszyński (1800-1893), a teacher in Raseiniai and Panevėžys, a bibliophile and author of several sermons and popular books for children, emphasized that death, as well as birth, should be treated as 'a famous event or fact'. The preacher traditionally appealed to the people not to sorrow for the dead, because they were on their way to eternity. On the other hand, the respect to the deceased and their merits were accentuated. Death had to be an impressive encouraging example to the living: "A Christian, witnessing the remains, similar to his own, already meant for heaven, finds many incentives to live an honest pious life". ${ }^{91}$ Speaking about Puslowski's life, the priest recalled that the deceased was not only a good Christian, but also a socially active person (Pol. obywatel), who knew his rights and adequately exercised them. In the sermon the social activeness of the deceased was considered his chief merit. Active participation in society's affairs was a male virtue. Among female virtues the features of a caring mother and devoted wife were listed; the dead woman was also referred to as a good citizen (obywatelka) who cared for poor unfortunates. According to Moszyński, all people were 'created' by society and therefore they were 'indebted' to it. God also created different estates and wanted them to coexist in society. The performance of estate duties was identified with that of religious rites..$^{92}$ The preacher praised the dead man,

${ }^{89}$ B. Rok. Człowiek wobec śmierci w kulturze staropolskiej. Wroclaw: Wydawnictwo Universitctu Wrockawskicgo, 1995, 21-22.

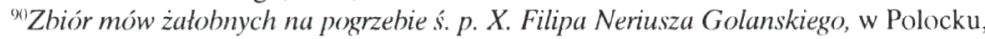
1824.

${ }^{91}$ A. Moszyński. Kazanie na pogrzebie jaśnie wielmożnych Woyciecha $i$ Józefy Puslowskich. Wilno, 1833, 5-6.

${ }^{92}$ Ibid., 11. 
because he had properly performed his estate duties and had abided by the rules, established by God. A good death implied the function of moral (religious) education and simultaneously had to strengthen the traditional - actually estate, religious - social order. Those issues were quite understandable taking into account the fact that the sermon was published after the uprising of 1831.

In addition to religious, class and family values, more secular, more universal and socially significant values were more often dealt with in funeral sermons and speeches. At the start of the century the ability to sacrifice one's personal interests for the love of fatherland and involvement in 'social activity'. Patriotism was conceived as the fundamental value, determining the life of human beings. ${ }^{93}$ One's education and scholarship were equally important, too. True, they were usually more valuable and useful, if combined with religion and tradition. Finally, one's positive, 'paternal' attitude towards the people was considered an important traditional moral value of the elite. ${ }^{94}$

Thus, 'the moment of death' educated and afforded examples of honest and fair behaviour, thus acquiring an important social function. The same was true of the funeral rituals. The descriptions of the burials and death commemorations of prominent people indicated not only their splendour (the number of candles burnt, the sums of money distributed among the beggars), but also the response of society, the numbers of participants, etc.

\section{Heroic Death}

In the 1870 s Józef Ignacy Kraszewski wrote: “...for many people the question of Poland was not limited by the way how to live and survive, but how to die". ${ }^{95}$ In their research on the development of Romanticism in the middle of the nineteenth century, Maria Janion and Maria Żmigrodska noted that in the period between the two uprisings of 1831 and 1863, a peculiar 'cult of death' originated in the progressive democratically minded society, which by no means could reconcile itself to the loss of statehood. For a certain section of society, especially the young, it seemed more important 'to die a beautiful death' rather than to conquer the enemy. Death increasingly came to be treated as a way of purging oneself of hideous enslavement and/or as redemption from the former 'faults' and 'sins'. True, the religious aspect became weaker, and the social 'faults' of the elite were accentuated to a greater degree, the gravest of them being the inability to

\footnotetext{
${ }^{93}$ Mowa na pogrzebic J O Xiążccia Jozefa Poniatowskiego przez Fran. Morawskiego pułkownika w Sedan, r. 1813. VIA, f. 1135, ap. 4, b. 512, 1. 3-4, 13.

${ }^{9} \mathrm{M}$. Valančius. Nauka w dzien pogrzebu.J.W. Wincentego Iwanowicza (?) wicemarszalka powiatu Rosienskiego (?), 183701 29. LLTIB RS, f. 1, (SD) 178, 1.n.

${ }^{95}$ J. I. Kraszcwski. Program Polski. Myśli o zadaniu narodowem. Poznań, 1872, 3.
} 
defend the statehood. The latter aspect was sometimes associated with the powerlessness 'to free' the peasants from serfdom. An excellent specimen of such sentiments and attitude towards death was the work and life of the Polish poet Mieczysław Romanowski, a participant of the uprising of $1863 .{ }^{96}$

In addition to existing cultural elements (particular attention to the moment of death, its didactic nature, etc.), new, culturally and socially significant elements appeared and intensified in the conception of death. The understanding of good death underwent modification primarily as a result of the secularization of society. The new, more secular attributes emerged next to their religious counterparts, ensuring eternal life. To die for meaningful and socially significant ideals (the freedom of one's motherland, the independence of the state, etc.) meant a fair death, especially if that was done of one's own free will. The formation of those and similar attitudes was not accidental. Their rise, doubtless, was influenced by the patriotic tradition of uprisings, inseparable from the sacrifices for the freedom. Such attitudes were also found in contemporary Lithuanian culture.

In the late eighteenth century the elite tradition maintained that the freedom of the country was unattainable without sacrifice, often ending in death. There were attempts to instil such ethical imperatives in lower social strata too, and in the first place to involve the peasantry in the uprising. Thus, one of the most prominent preachers of the late eighteenth century Mykolas Karpavičius declared: "There can be no greater glory and honour than a heroic death of a soldier for the Fatherland". ${ }^{97}$. The love of fatherland requires sacrifice, and 'martyrs of patriotism' and those loving their homeland will be saved by the Lord. The copies of that sermon, delivered in St John's church in Vilnius in May 1794, on the orders of the uprising leaders had to be 'immediately' distributed among the military and 'the citizens' and to be read for the peasants in the parish churches.

A close connection between death and patriotism and between death and freedom modified the attitude to those forms of death (e.g., suicide) which were condemned in previous religious tradition. Furthermore, there started a glorification of historical personages who preferred voluntary death to slavery. In his Büdas senoves Lietuviu, kalnènu ir Žemaičiu (1845) Daukantas mentioned Lithuanian warriors including Margiris, who committed suicide rather than yield to the enemy. In his work Pasakojimas apie veikalus Lietuviu tautos senoveje, written about 1850-54 and first published in 1899, Daukantas called

"M. Janion, M. Żmigrodska. Romantyzm i historia. Warszawa: Państwowy Instytut Wydawniczy, 1975, 541 .

"Tado Kosciuškos sukilimo (1794) lietuviški raštai [Lithuanian writings of the uprising of Thaddcus Kosciusko (1794)]. Prcp. by J. Tumclis. Historiae Lituaniae Fontes Minores, t. 1, Vilnius: Žara, 1997, 25(7). 
Margiris a freedom fighter, who committed suicide, because he did not want to live in slavery. ${ }^{98}$ Margiris was similarly treated by Vladislavas Sirokomle (Władisław Syrokomle) in his popular poem, written in the mid-nineteenth century and entitled by the name of the hero. In 1883 the poem was published in a slightly shortened form in the periodical Aušra. Even the bishop of Samogitia, Motiejus Valančius, wrote about Margiris in his book for children Pasakojimas Antano Tretininko - the hero burned himself in order to avoid slavery and 'dreadful death' ${ }^{99}$ In all those works the suicide of Margiris was characterized as a heroic deed, done for the freedom of the Fatherland. Later, in the army of the Republic of Lithuania Margiris became a symbol of military virtue. 